\author{
Dorota Habrat \\ University of Rzeszów, Poland \\ ORCID: 0000-0002-5411-0323 \\ dhabrat@ur.edu.pl
}

\title{
Protection of Human Dignity as a Basis for Penalization of Hate Speech against People with Disabilities in Polish Criminal Law
}

\author{
Ochrona godności człowieka jako podstawa penalizacji \\ mowy nienawiści wobec osób z niepełnosprawnościami \\ w polskim prawie karnym
}

\begin{abstract}
The aim of the study is a legal analysis of the provisions criminalizing hate speech in Polish criminal law, in terms of the protection of inherent human dignity in relation to people with disabilities. Rated whether the absence of special protection under criminal law in the area of hate speech provides the proper respect and protects the dignity of persons with disabilities in Poland, to the same extent and degree as other people. The doctrine of criminal law protection against hate speech was discussed. It was analysed why hate speech against people with disabilities was not penalized and it was shown that legal changes in this area should be preceded by a multifaceted legal analysis, taking into account international standards, and proposals for amendments were characterized by an insufficient justification of the inalienable value of dignity. A discussion was held on the basis of criminalizing hate speech against people with disabilities. It has been shown that extending protection against hate speech to people with disabilities is not questionable and should be based on ensuring that dignity is adequately protected by the rule of law in order to counterbalance limitations resulting from the feature of disability, which is essentially independent of them.
\end{abstract}

Keywords: criminal law protection; people with disabilities; human dignity; hate speech

CORRESPONDENCE ADDRESS: Dorota Habrat, PhD, Assistant Professor, University of Rzeszów, College of Social Sciences, Institute of Legal Studies, Grunwaldzka 13, 35-068 Rzeszów, Poland. 


\section{INTRODUCTION}

Every human being, even those afflicted with a disability of their body or psyche, has dignity and special value from the beginning of their existence until their natural death. The protection of persons with disabilities in Polish criminal law is a complex issue. Even a cursory examination of this problem suggests that it can be considered in various contexts and against the background of various regulations. It must be said that, like any human being, a person with a disability is subject to extensive protection by the norms of criminal law. Special care for people with disabilities in Poland should result from, among other things, Article 30 of the Polish Constitution ${ }^{1}$ of the principle of inherent and inalienable human dignity. The dignity of a human being constitutes his/her subjectivity and autonomy. Thus, public authorities have a special duty to protect human dignity. This protection is particularly important for people with disabilities, who find it difficult to sufficiently independently care for their subjectivity.

The obligation to protect people with disabilities also arises from the international obligations of the Republic of Poland, in particular, the Convention on the Rights of Persons with Disabilities adopted by the United Nations General Assembly on 13 December 2006. ${ }^{2}$ In this Convention, the international community affirmed the need to protect the dignity of such persons. It committed states to adopt effective legal measures to eliminate injustice, discrimination, and violations of the rights of persons with disabilities. The Convention makes frequent reference to the concept of dignity, not only in the Preamble but also in its essential content. Article 1 already refers to respect for the inherent dignity of persons with disabilities. It should be noted that in Europe, dignity is beginning to be interpreted in two ways - as a fundamental right in itself and as the real basis of fundamental rights. ${ }^{3}$

Convention on the Rights of Persons with Disabilities in Article 12 promotes the right of people with disabilities to be subjects before the law and therefore with legal capacity in all spheres of life. It is, therefore, necessary to support this group of people to prevent any abuse. The purpose of the Convention is to promote, protect, and ensure the full and equal enjoyment of all human rights and fundamental freedoms by all persons. ${ }^{4}$ It explicitly states respect for the inherent dignity of persons

${ }^{1}$ Constitution of the Republic of Poland of 2 April 1997 (Journal of Laws 1997, no. 78, item 483, as amended). English translation of the Constitution at: www.sejm.gov.pl/prawo/konst/angielski/ kon1.htm [access: 10.09.2021].

${ }^{2}$ Convention on the Rights of Persons with Disabilities adopted by the UN General Assembly on 13 December 2006 (Journal of Laws 2012, item 1169, as amended), hereinafter: Convention.

${ }^{3}$ B. Mikołajczyk, Międzynarodowa ochrona praw osób straszych, Warszawa 2012, p. 108.

${ }^{4}$ E. Bieńkowska, Wiktymologia, Warszawa 2018, p. 221. 
with disabilities, individual autonomy, including the freedom to make one's own choices, and independence of persons. ${ }^{5}$

It should be recognized that any violation of human rights is a violation of dignity. However, some categories of people, e.g., people with disabilities, because of their characteristics, are particularly vulnerable to actions which constitute the most severe violation of their dignity. Usually, these violations arouse fierce opposition from world public opinion, but often the community is left helpless against it. Hate speech against people with disabilities is a kind of crime that is an everyday experience for many of them, leaving significant psycho-emotional scars. At this point, it can be argued that people with disabilities do not have sufficient support in Poland to protect their dignity against hate speech. Provisions in criminal law do not seem to sufficiently protect this social group, due to the issue of the dignity of persons with disabilities as a basis for special protection. The reasons for the ineffectiveness of the change in the catalogue of features subject to special protection against hate speech by including people with disabilities require analysis. The time frame of the last decade will be considered in this regard.

The aim of this article is a legal analysis of the provisions criminalizing hate speech in terms of the protection of inherent human dignity in relation to people with disabilities. This problem, despite the spreading of the idea of human rights, the development of society in the spirit of empathy and understanding of others, respect for their dignity, and the functioning of the law prohibiting discrimination, still often appears in society through negative attitudes connected with shame, lack of understanding, lack of basic feelings or ignorance of the essence of disability.

\section{DIGNITY OF PERSONS WITH DISABILITIES AS A BASIS FOR SPECIAL PROTECTION IN CRIMINAL LAW}

Disability is about human beings, their sense of dignity, acceptance, and empathy of society. People with disabilities are equipped with the ability to make informed choices, ${ }^{6}$ and respect for the dignity of each individual is a cornerstone of a pluralistic democratic society.

Dignity is understood as a special value of a human being as a person in interpersonal relations, justifying and determining the sense of personal life, as well as positively valuing relations to one's own person and the group with which one identifies oneself. The concept of dignity is complex, ambiguous and multivalent,

${ }^{5}$ R. Lang, The United Nations Convention on the right and dignities for persons with disability: A panacea for ending disability discrimination?, "Alter. European Journal of Disability Research" 2009, vol. 3(3), p. 267.

${ }^{6}$ Ibidem, p. 273. 
it can be considered in various aspects, e.g. philosophical, psychological, religious or legal. ${ }^{7}$

Human dignity is inseparably connected with the whole system of civil liberties and rights, it is an essential component of the principle of a democratic state of law, and thus a binding legal norm. It determines the legal and positive status of an individual in the constitutional order of the Republic of Poland, and at the same time it defines the essence of humanity in the fullest way. ${ }^{8}$ Personal dignity as an attribute acquired during life is not permanent, it is subject to various fluctuations, it may be completely destroyed, among other things, under the influence of external factors. ${ }^{9}$

Dignity is not relative, but absolute. ${ }^{10}$ Consequently, the absolute nature of the dignity of every human being precludes differentiation or gradation. It does not depend on social or material status, merit, education, physical or intellectual fitness, mental state, age, nationality, race, religion or language, or any other incidental human characteristics or social values, but on the very fact of belonging to the human race. ${ }^{11}$ Every human being as a human being has dignity. Man is born with his personal dignity, and any attempts to deprive man of his dignity do not diminish it. ${ }^{12}$ The essence of the principle of human dignity is, first of all, to guarantee everyone a position that prevents him from being treated as an object of actions by others and an instrument in the realization of any goals. This law implies the prohibition of any objectification of a human being and the order to treat them subjectively. ${ }^{13}$

The absolute duty to treat all people subjectively is a moral imperative stemming from the unconditional nature of human personal dignity. This means that personal dignity is independent of any human traits and characteristics including disability. Personal dignity is therefore bestowed upon persons affected by one or another type of disability.

${ }^{7}$ More broadly, see N. Jacobson, Dignity and health: A review, "Social Science \& Medicine" 2007, vol. 64(2), pp. 292-302; M. Borski, Godność człowieka jako wartość uniwersalna, "Przegląd Prawa Publicznego" 2014, no. 3, pp. 7-20.

8 A. Deryng, Zasada poszanowania godności osoby ludzkiej w praktyce konstytucyjnej Rzecznika Praw Obywatelskich, [in:] Wptyw standardów międzynarodowych na rozwój demokracji i ochronę praw człowieka, ed. J. Jaskiernia, vol. 3, Warszawa 2013, p. 557; P. Polak, J. Trzciński, Konstytucyjna zasada godności człowieka w świetle orzecznictwa Trybunału Konstytucyjnego, "Gdańskie Studia Prawnicze" 2018, no. 2, pp. 257-274.

9 A. Mikrut, O promowaniu godności człowieka w ramach Konwencji o prawach osób niepetnosprawnych, "Rocznik Komisji Nauk Pedagogicznych" 2016, vol. 69, p. 109.

10 M. Granat, Godność człowieka z art. 30 Konstytucji RP jako wartość i jako norma prawna, "Państwo i Prawo" 2014, no. 8, pp. 3-22.

11 A. Deryng, op. cit., p. 546.

12 B. Szczupał, Godność osoby z niepetnosprawnościa jako wyznacznik koncepcji praw człowieka, "Człowiek-Niepełnosprawność-Społeczeństwo" 2012, no. 3, p. 30.

13 S. Zieliński, Rozumienie godności człowieka i jej znaczenie w procesie stanowienia i stosowania prawa. Propozycja testu zgodności regulacji prawnych z zasada godności człowieka, "Przegląd Sejmowy" 2019, no. 4, p. 120. 
The role of human dignity in the area of human rights was analysed by R. Andorno,${ }^{14}$ pointing to the existing relationships between these concepts and emphasizing the importance of dignity in this context. The appeal to dignity reflects genuine concern for respect for the intrinsic value of human rights and promotion of the preservation of identity. ${ }^{15}$ The meaning of human dignity is the theoretical axiom or moral value underlying the ideal of "Good" and collective duty in society. As such, human dignity can play an important role in research. ${ }^{16}$ It follows that dignity should play a more prominent role in the discussions and analysis in the field of normative legal issues relating to human rights.

Human rights express the objective conditions for the realization of such issues that constitute the value of human beings as a species. Presented as norms, they tell us how each person should treat and be treated by other people in order to have the opportunity to realize these potentialities. ${ }^{17}$ So what we call "human dignity" means awareness of the value of man. It is this value that makes each person worthy to be treated in such a way as to be able to live in harmony with himself. It can therefore be said that human dignity is a subjective correlate of his objective value.

The problem of the perception of dignity is also related to social and technical development, which is also reflected in research. ${ }^{18}$ In this regard, researchers point to the dangers of re-evaluating the social understanding of dignity especially in conjunction with technological implications. This, unfortunately, can have implications in misjudging legal norms.

Respect for the inherent dignity of people with disabilities, including the freedom to make their own choices, is based on the belief that such people have the ability to make informed choices for themselves. ${ }^{19}$ As disability is perceived differently in different environments, disability is perceived in a complex and varied manner. This can lead to discriminatory behaviour. We currently live in a social paradigm designed with the human rights of people with disabilities in mind. This new model has been adopted in most countries of the world. This is in line with the so-called equality policy, i.a. as a result of joint actions in the field of law-making. However, regardless of these actions, there are cases of hate speech against people with disabilities that affect issues related to the escalation of social

${ }^{14}$ R. Andorno, Human Dignity and Human Rights as a Common Ground for a Global Bioethics, "Journal of Medicine and Philosophy" 2009, vol. 34, pp. 223-240.

15 B.E. Gibson, B. Secker, D. Rolfe, F. Wagner, B. Parke, B. Mistry, Disability and dignity-enabling home environments, "Social Science and Medicine" 2012, vol. 74(2), pp. 211-219.

16 P. Gilabert, Human Dignity and Human Rights, Oxford 2019.

17 N. Jacobson, op. cit., pp. 292-302.

${ }^{18}$ I. Kuçuradi, The concept of human dignity and its implications for human rights, "Bioethics Update" 2009, vol. 5, pp. 7-13.

19 R. Lang, op. cit., pp. 266-285. 
exclusion. ${ }^{20}$ With regard to persons with disabilities are at greater risk of violation of their dignity as a result of the restrictions they have. These issues are the subject of complex analyses and studies that show the need for greater sensitivity towards this social group. ${ }^{21}$

Personal dignity is the source of human rights, but it is the state law that determines the real and not merely the ideological existence of this right. Thus, to ensure adequate rights for persons with disabilities in view of their personal dignity, adequate legal protection, including criminal law protection, is necessary. This is necessary to create specific living conditions, support structures, and legal protections that respond to the needs and developmental dynamics of a person with disabilities. ${ }^{22}$ Therefore, the starting point should be the necessity to guarantee that people with disabilities can enjoy all human and civil rights to the same extent and scope as any other person. ${ }^{23}$

Over the past decades, the United Nations has initiated a number of important legal regulations aimed at respecting and upholding the personal dignity of persons with disabilities. These initiatives act as a catalyst for national legislative, executive, and consultative bodies to take action in this field. The Convention on the Rights of Persons with Disabilities is a good example of this. The obligations of the States that have ratified the Convention in this regard are expressed in a number of articles, as the Convention promotes a long list of rights and freedoms that should be enjoyed on an equal basis with others.

Man is a physical-spiritual whole, which is the basis of his inherent, inviolable and inalienable dignity, including that experienced by even the most profound disturbances of development and functioning. Due to the so-called personal dignity, every human being deserves respect and fair treatment on the part of others. This means that the dignity of a person with a disability should be respected and protected to the same extent and to the same scope as for all other people. ${ }^{24}$ Therefore, rights based on that dignity, including the right to criminal law protection, should also be subject to specific protection going beyond the scope of persons without the listed additional social group characteristics.

20 J.A.G. Monedero, C.U. Cuesta, B.N. Angulo, Social Image of Disability. Vulnerability of the Dignity of Women with Disability and Social Exclusion Contexts, "Procedia - Social and Behavioral Sciences" 2014, vol. 161, pp. 115-120.

${ }^{21}$ K. Zdravkova, Reconsidering Human Dignity in the New Era, "New Ideas in Psychology" 2019, vol. 54, pp. 112-117.

22 A. Mikrut, O promowaniu godności..., p. 111.

${ }^{23}$ B. Gąciarz, Model społeczny niepetnosprawności jako podstawa zmian w polityce społecznej, [in:] Polscy niepetnosprawni. Od kompleksowej diagnozy do nowego modelu polityki społecznej, eds. B. Gąciarz, S. Rudnicki, Kraków 2014, p. 34.

${ }^{24}$ A. Mikrut, O poszanowaniu godności osób niepetnosprawnych - idea a rzeczywistość, "Pielęgniarstwo i Zdrowie Publiczne" 2013, no. 3-4, pp. 385-391; idem, O odkrywaniu swojej godności przez osoby z niepetnosprawnościa intelektualną, "Annales UMCS. Sectio J”2014, vol. 27(1), pp. 19-33. 
Protection of Human Dignity as a Basis for Penalization of Hate Speech against People... 265

\section{THE DOCTRINE OF LEGAL PROTECTION AGAINST HATE SPEECH}

The issue of criminal law protection against hate speech is a subject of significant social interest and refers to the criminal liability of the so-called "haters". The problem is first and foremost that increasing the degree of protection against behaviour based on prejudice against certain social groups and individuals within them is connected with the issue of freedom of expression.

It is well known that hate speech is considered statements that incite hatred as well as those that express hatred. Thus, the discredited entity may be a person or group of persons belonging to or constituting not only a particular minority, but also belonging to or constituting a particular majority. A characteristic of hate speech is that it involves prejudice due to certain discriminatory characteristics. Without motivation based on prejudice, there is no hate speech even if there is insult.

Hate speech can intimidate, threaten, humiliate, offend, as well as perpetuate stereotypes and lead to discrimination and even physical violence. ${ }^{25}$ The factor that causes a statement to be interpreted as hate speech is the nature of its content, which is evaluated objectively in the process of confronting it with the rules of social coexistence. ${ }^{26}$

Protection from hate speech is a contemporary aspect of the protection of human rights to dignity. It should be noted in this context that we are dealing with hate speech when the sole purpose of such speech is to express contempt or humiliation of a human being. The classification of hate speech and the proper response to this type of criminal behaviour can be problematic. Taking action against hate speech is sometimes considered an unjustified restriction on freedom of speech. In considering questions of the limits of free speech, one must consider the degree of harm in the speech in question. There are no clear criteria for determining the degree of such harm. Hence, the response to hate speech should not be too restrictive of freedom of speech, but must be adequate to the damage it causes or may cause.

The catalogue of goods protected by hate crime legislation should include those values that become frequent targets of attack in a given country. These are most often values inherent to the identity of members of certain social groups who are potential victims of this type of crime.

${ }^{25}$ A. Śledzińska-Simon, Decyzja ramowa $w$ sprawie zwalczania pewnych form i przejawów rasizmu i ksenofobii jako trudny kompromis wobec mowy nienawiści w Unii Europejskiej, [in:] Mowa nienawiści a wolność stowa. Aspekty prawne i społeczne, eds. R. Wieruszewski, M. Wyrzykowski, A. Bodnar, A. Gliszczyńska-Grabias, Warszawa 2010, p. 94; K. Machowicz, Jurydyczne uwarunkowania wolności wypowiedzi w Polsce jako kategoria praw człowieka w Polsce, Lublin 2012, p. 50.

${ }^{26}$ L.K. Jaskuła, Wolność działalności dziennikarskiej w perspektywie zjawiska mowy nienawiści (wybrane aspekty prawne), [in:] Status prawny dziennikarza, ed. W. Lis, Warszawa 2014, p. 319. 
In Recommendation no. R (97) 20 adopted by the Committee of Ministers of the Council of Europe on 30 October 1997, 27 "hate speech" is considered any form of expression that disseminates, incites, promotes or justifies racial hatred, xenophobia, anti-Semitism and other forms of hatred based on intolerance, including intolerance expressed in violent nationalism and ethnocentrism, discrimination and hostility towards minorities, immigrants and people of immigrant origin. Such an understanding of hate speech was referred to, i.a., by the Supreme Court in its judgement of 8 February $2019 .{ }^{28}$

The pejorative features of hate speech depend on the perception of the victim. For some, it may or may not affect. It can be shown that the effect of hate speech depends on the originator, content and the targeted one. ${ }^{29}$ Hate speech is intended to injure, dehumanize, harass, intimidate, debase, degrade, and victimize the targeted groups, and to foment insensitivity and brutality against them. ${ }^{30}$

Although in the Polish legal language there is no term "hate speech", it is already a permanent element of the legal language - jurisprudence and legal doctrine. The literature emphasizes that "the hierarchy of protection for victims of hate speech is being created in the current state of law". 31

From the point of view of hate speech, mainly two provisions are relevant in criminal law -Articles 256 and 257 of the Polish Penal Code.$^{32}$ In accordance with the provision of Article $256 \mathrm{PC}$ whoever publicly propagates a fascist or other totalitarian system of the state or incites to hatred on the grounds of national, ethnic, racial, religious differences or on the grounds of irreligiousness shall be subject to group of people or public insult or violation of bodily integrity of a person because of his/her national, ethnic, racial, religious affiliation or because of his/her irreligiousness.

The norms contained in these provisions create certain doubts or disputes of practical nature. Judicial jurisprudence and legal doctrine highlight the difficulties of interpreting the phrase "incitement to hatred", i.e., in the conduct of a person, who publicly presents the negative characteristics of the persons referred to in Articles 256 and $257 \mathrm{PC}$, there is no aspiration to cause negative emotions in other

${ }^{27}$ Recommendation no. R (97) 20 of the Committee of Ministers to Member States on "hate speech", adopted by the Committee of Ministers on 30 October 1997.

${ }^{28}$ IV KK 38/18, LEX no. 2621830.

29 N. Chetty, S. Alathur, Hate speech review in the context of online social networks, "Aggression and Violent Behavior" 2018, vol. 40, pp. 108-118.

${ }^{30}$ R. Cohen-Almagor, Fighting Hate and Bigotry on the Internet, "Policy \& Internet" 2011, vol. 3(3), pp. 89-114.

${ }^{31}$ E. Rogalska, M. Urbańczyk, Złożoność zjawiska mowy nienawiści w pozaprawnym aspekcie definicyjnym, "Studia nad Autorytaryzmem i Totalitaryzmem" 2017, vol. 39(2), p. 117.

32 Act of 6 June 1997 - Penal Code (consolidated text, Journal of Laws 2020, item 1444, as amended), hereinafter: PC. 
people, then such a person cannot be attributed with the realization of the elements of this crime..$^{33}$ The Supreme Court in the decision of 5 February $2007^{34}$ interpreting the phrase "incites to hatred", explained that "incitement to hatred on the grounds listed in Article 256 PC [...] boils down to such statements that arouse feelings of strong dislike, anger, lack of acceptance, even hostility towards individuals or entire social or religious groups or, because of the form of expression, maintain and intensify such negative attitudes and thus emphasize the privilege or superiority of a particular nation, ethnic group, race or religion". The key is the impact of the perpetrator on the psyche of others, involving the intention to arouse in them "the strongest negative emotion, similar to hostility" to a particular person or social group. ${ }^{35}$ The Constitutional Tribunal in its judgement of 25 February $2014^{36}$ ruled that the courts should take into account, when interpreting Article $256 \S 1$ PC, the principle of freedom of expression, which is a right guaranteed by the Polish Constitution and consistent with international and local standards. The Tribunal stressed that although the criminalization of incitement to hatred based on national, ethnic, racial, and religious differences undoubtedly restricts the freedom of expression, this restriction is consistent with the Polish Constitution and is necessary in a democratic society to ensure public order, as well as to protect the rights of other citizens.

It is obvious that the confrontation of hate speech with freedom of speech causes controversy in terms of drawing the line between what is offensive and should be banned and what is permissible under freedom of expression. ${ }^{37}$ It is beyond dispute, however, that incitement to hatred on the basis of certain differences is not just the expression of controversial views, which should of course be guaranteed, but a clear abuse of freedom of speech, aimed directly at causing or fuelling conflict. ${ }^{38}$

Human rights doctrine, to protect specific and socially important values and to unify the position within the international community, tries to develop standards to understand the concept of hate speech. ${ }^{39}$ This approach provides a basis for the

33 A. Demczuk, Wolność wypowiedzi w orzecznictwie Europejskiego Trybunału Praw Człowieka a polskim prawie i praktyce sądowej, [in:] Europejska konwencja o ochronie praw czlowieka - praktyka stosowania i funkcjonowanie w przestrzeni europejskiej, eds. M. Haczkowska, F. Tereszkiewicz, Opole 2016, p. 151.

${ }^{34}$ IV KK 406/06, OSNwSK 2007, no. 1, item 367.

35 D. Gruszecka, Przestępstwa przeciwko porzadkowi publicznemu, [in:] Kodeks karny. Część szczególna. Komentarz, ed. J. Giezek, Warszawa 2014, p. 917.

${ }^{36}$ SK 65/12, OTK 2014, no. 2, item 14.

37 A. Śledzińska-Simon, op. cit., p. 99

38 W. Mojski, Prawnokarne ograniczenia wolności wypowiedzi w polskim porzadku prawnym: analiza wybranych przepisów, "Studia Iuridica Lublinensia” 2009, vol. 12, pp. 193-194.

39 A. Gliszczyńska-Grabias, Międzynarodowe standardy wolności stowa a mowa nienawiści, [in:] Mowa nienawiści w Internecie. Jak z niq walczyć? Materiały z konferencji, eds. D. Bychawska-Siniarska, D. Głowacka, Warszawa 2013, p. 45. 
implementation and evolution of national law within a given scope, taking into account legal specificities and the body of case law. The analysis carried out within the framework of this study is in line with this, which on the one hand goes out of the box by referring to the issue of hate speech towards people with disabilities, while at the same time referring to international standards. Comprehensive approach to the indicated problems taking into account multifaceted legal research provides a basis for formulating de lege ferenda conclusions.

\section{ANALYSIS OF THE REASONS FOR NOT INTRODUCING THE PENALIZATION OF HATE SPEECH AGAINST PEOPLE WITH DISABILITIES}

Hate speech is a particular form of human rights violation. ${ }^{40}$ The question arises whether there is a need to criminalize the behaviour of inciting hatred on the basis of disability. In the past several years, there have been a number of proposals to amend the criminal provisions typifying hate speech crimes. The source of these proposals should be sought in the transformation of attitudes towards certain characteristics of certain social groups and the individuals belonging to them. Table 1 summarizes those proposed changes to the legislation that expand the catalogue of characteristics covered by hate speech protection and include people with disabilities. Selected opinions of the National Council of the Judiciary, the Supreme Court, the Supreme Bar Council, the Prosecutor General and the Polish government were presented. It should be noted that all presented attempts to amend discrimination legislation have failed. The analysis in this respect will allow determining the reasons for not introducing the penalisation of hate speech to people with disabilities. The problem is more complex because some victims, including people with disabilities, are particularly vulnerable during criminal proceedings to secondary and repeat victimisation, intimidation, and retaliation by the offender. This risk may be related to the personal characteristics of the victim, the type or nature, and the circumstances of the crime.

${ }^{40}$ Metodyka pracy adwokata i radcy prawnego w sprawach o przestepstwa z nienawiści, ed. P. Knut, Warszawa 2020, p. 338. 
Pobrane z czasopisma Studia Iuridica Lublinensia http://studiaiuridica.umcs.pl

Data: 26/04/2023 08:01:36

Protection of Human Dignity as a Basis for Penalization of Hate Speech against People... 269

\begin{tabular}{|c|c|c|c|c|c|}
\hline 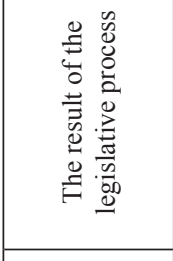 & 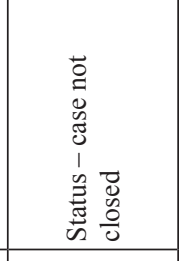 & 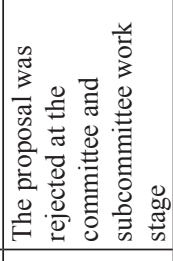 & 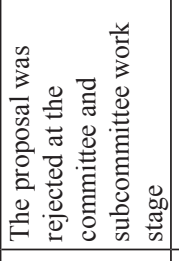 & 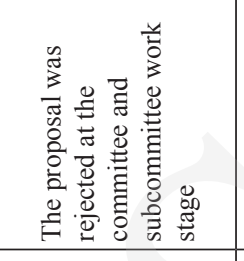 & 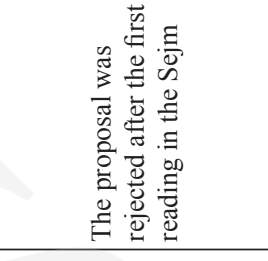 \\
\hline 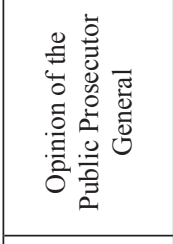 & 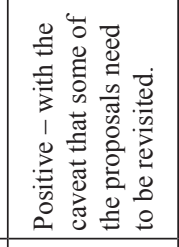 & 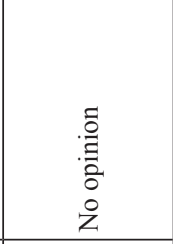 & 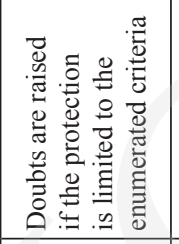 & 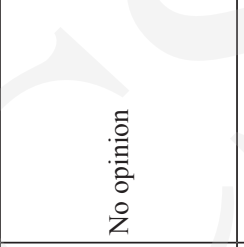 & 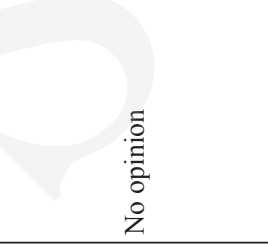 \\
\hline 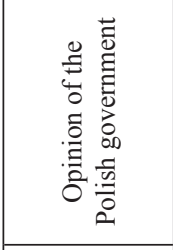 & 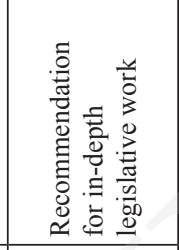 & 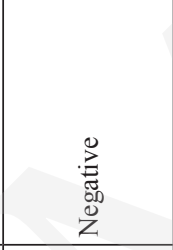 & 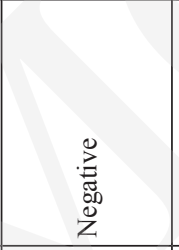 & 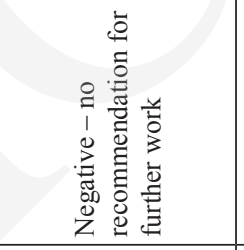 & $\begin{array}{l}\text {.0̊ } \\
\text { 产 } \\
\text { : } \\
\text { ż }\end{array}$ \\
\hline 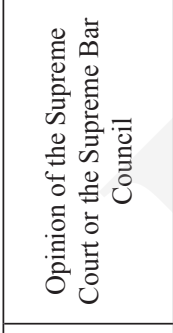 & 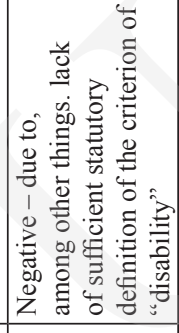 & 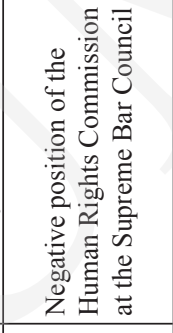 & 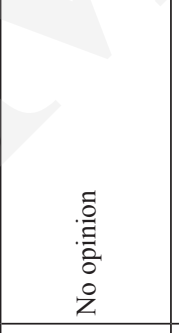 & 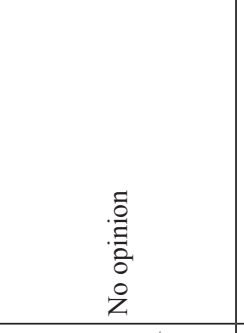 & 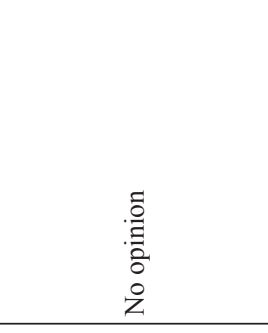 \\
\hline 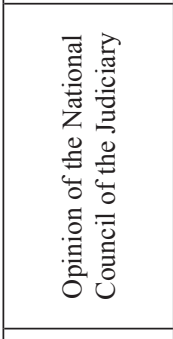 & 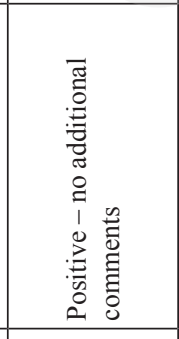 & 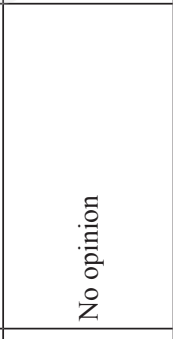 & 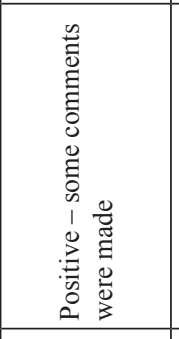 & 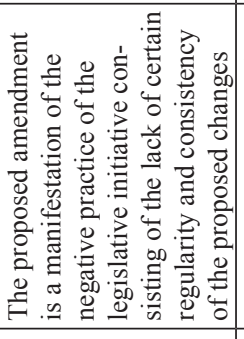 & 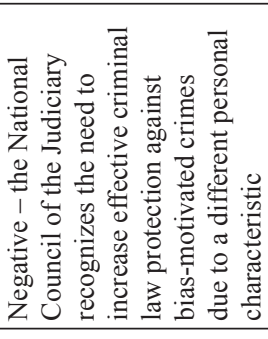 \\
\hline 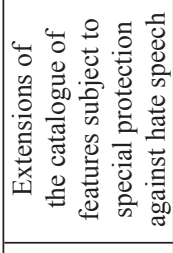 & 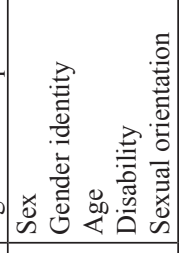 & 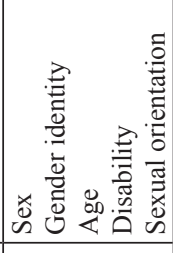 & 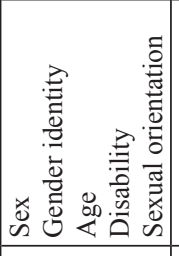 & 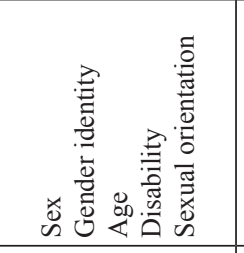 & 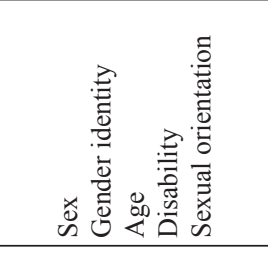 \\
\hline 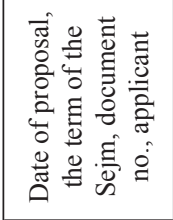 & 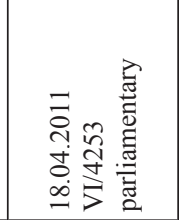 & 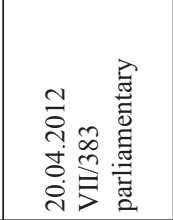 & 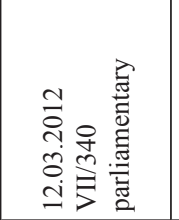 & 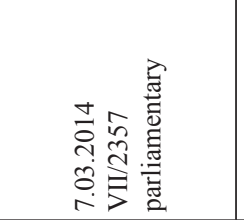 & 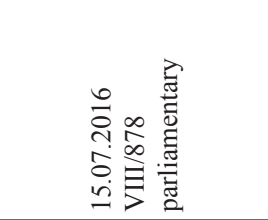 \\
\hline
\end{tabular}


Pobrane z czasopisma Studia Iuridica Lublinensia http://studiaiuridica.umes.pl

Data: 26/04/2023 08:01:36

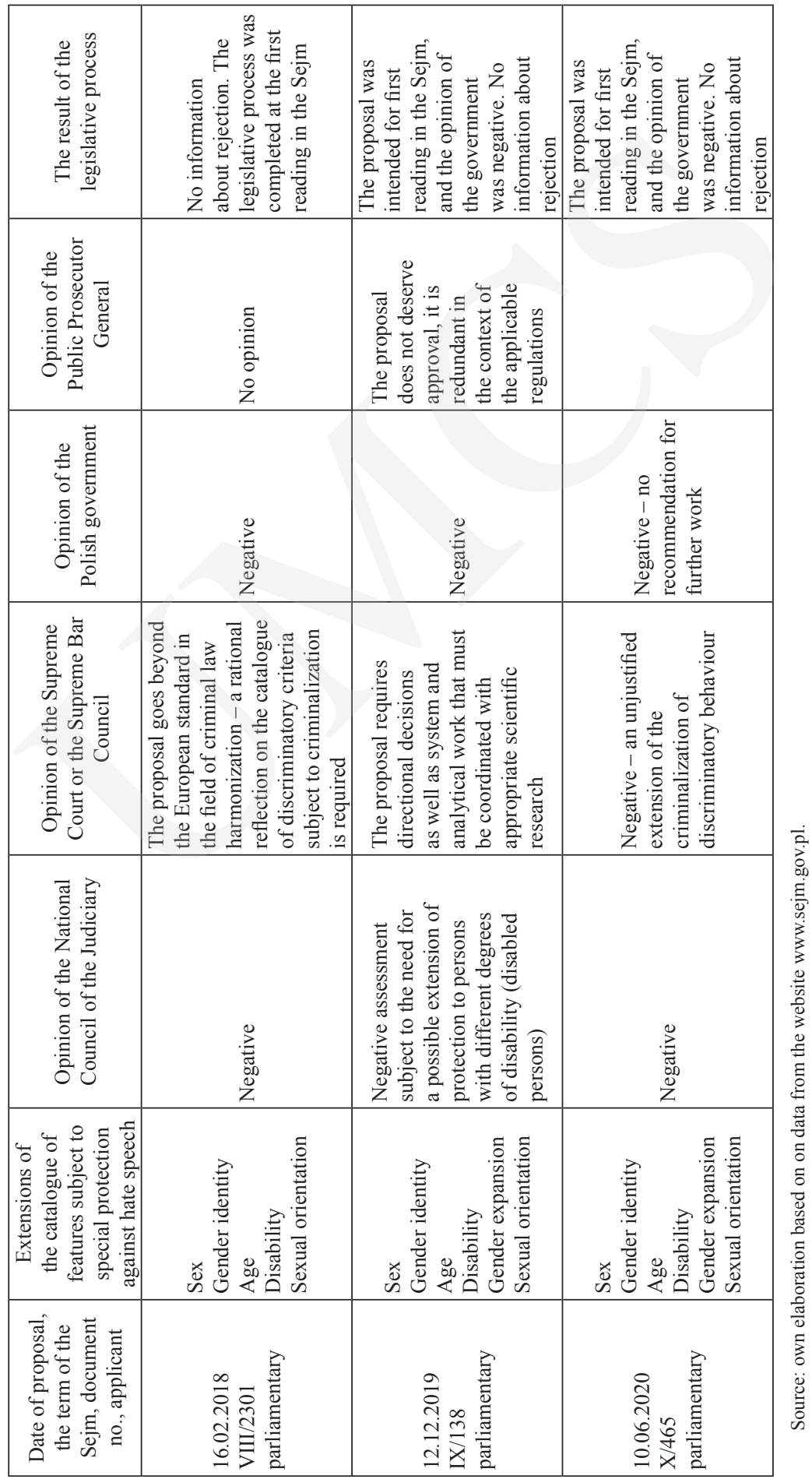


The first proposal to amend the legislation in the period under analysis was a parliamentary bill in the Sejm of the $6^{\text {th }}$ term (Print no. 4253). It proposes to expand the catalogue of characteristics subject to special protection against hate speech to include gender, gender identity, age, sexual orientation and disability, which is the subject of this discussion. Despite the positive opinions of both the National Council of the Judiciary and the General Prosecutor, the proposal was not adopted. It was not rejected at first reading, but its status remained at the "case not closed" status. The Supreme Bar Council pointed out that the proposal narrows the scope of criminalisation in relation to the current wording into an effectual type. At the same time, reservations regarding the sufficient statutory specificity of the "disability" criterion were also indicated. One should agree with this opinion in terms of the significance of precision, because the provision refers to the sphere of freedom of speech as a constitutional value, defining its impassable limits. The next three deputies' proposals were submitted in the Sejm of the $7^{\text {th }}$ term, taking into account the same scope of extending the catalogue of characteristics subject to special protection. In principle, it can be assessed that they were a reference to the activities undertaken under the above-mentioned project of the Sejm of the $6^{\text {th }}$ term.

These proposals were not recognized by the Polish government's position. It was also indicated that the extension of the catalogue of criteria for groups subject to special protection to include "gender, gender identity, disability, age and sexual orientation" raises concerns as to the precision of individual concepts and the completeness of the criteria. Despite the fact that the projects include case studies and confirmation of the legitimacy of introducing regulations with appropriate statistics, one cannot resist the impression of certain chaos and duplication of previous patterns. There is no specific concept of justifying the amendments with structured arguments and discussion.

The above-mentioned errors in the justification are not included in the parliamentary proposal of the Sejm of the $8^{\text {th }}$ term (Print no. 878). The authors clearly defined the purpose of the amendment and the good protected by law, and the entire justification was clearly referenced in the literature and statistical analyses. However, there is a noticeable lack of reference to the constitutional protection of human dignity. However, the proposed changes are not limited only to expanding the catalogue of protected premises - changes have also been introduced to clarify the current regulations in order to ensure uniform interpretation.

The current wording of these provisions allows for an interpretation that narrows the criminal law protection to persons who actually are the bearers of a given feature. Using such an interpretation, victims are excluded from protection, e.g. of violence, who although they do not have a specific feature themselves, but their victimization results from being associated with a person who has a specific feature, or from the fact that they are perceived by the environment as people with a specific feature. However, it can be argued that even better justification would 
not be appreciated by the legislator, as the proposal rejection in the first reading was only supported by the laconic opinion of the National Council of the Judiciary.

The legitimacy of a possible extension of protection against hate speech against persons of varying degrees of ability was indicated by the National Council of the Judiciary in its opinion on the proposal in the Sejm of the $9^{\text {th }}$ term (Print no. 138). In the case of this draft, all opinions were negative, It is worth noting that the Supreme Court rationally justified the need to analyse the discriminatory criteria covered by the criminalization. He pointed to the need for the notion of directional decisions as well as system and analytical work, which must be coordinated with relevant scientific research.

The last proposal from the analysed period, in principle, does not justify in detail the need to extend the catalogue of features subject to special protection against hate speech, and it did not meet with the favour of the Supreme Court, the National Council of the Judiciary and the Polish government. However, it is possible to point out the rather peculiar reasoning of the Supreme Court, in which the lack of legitimacy of the changes in the characteristics subject to special protection was stated that "it is about a completely different category of people", without providing rational arguments for its opinion.

By analysing the amendment proposal to Article $256 \mathrm{PC}$, it can be pointed out that, first of all, there is a similarity in the proposed to add a catalogue of features subject to special protection against hate speech, which includes, in addition to disability, gender, gender identity, age and sexual orientation. In fact, only the last two drafts additionally included gender expression. However, it is characteristic that disability always occurs in a package with other characteristics with significant polarization in socio-political evaluation such as gender identity, sexual orientation, or gender expression. Without assessing at this point the legitimacy of the introduction of other factors of discrimination by way of hate speech, it could be concluded that the ineffectiveness of the extension of the scope of criminalization of Article 256 PC about people with disabilities can result from considering it together with other characteristics. This thesis is confirmed by the negative assessment of the National Council of the Judiciary for the proposal of 12 December 2019, in which there is a reservation about the need to extend protection to people with different degrees of disability.

Among the main non-political problems with the failure to make changes for people with disabilities are issues related to the sufficiency of the statutory definition of the criterion of "disability" and the failure to adequately argue for the inclusion of additional criteria for protection against discrimination. It should be noted that the opinion of the Supreme Court, which is not unfounded, speaks of the need for systemic and analytical work and scientific research that must precede such proposals.

It is clear that effective identification of the presence of risks arising from a particular characteristic of a victim is only possible on the basis of an individual assess- 
ment, carried out at the earliest possible stage. Such an assessment should be carried out for all victims to determine what specific protection measures they need. ${ }^{41}$ The individual assessment should take into account the personal characteristics of the victim, including disability and the nature and circumstances of the crime. ${ }^{42}$

\section{DISCUSSION ON THE BASIS FOR PENALIZING HATE SPEECH AGAINST PEOPLE WITH DISABILITIES}

There is no agreement in the science of criminal law regarding the need for enhanced protection of persons with disabilities against hate speech. Scepticism is expressed about the role of criminal law in combating hate speech, with a simultaneous indication of the need to take action in this area on the basis of family, civil and administrative law. ${ }^{43}$ In turn, other authors draw attention to the disproportion in the level of intensity of protection of persons and groups distinguished on the basis of race, nationality, ethnic origin, religion or irreligiousness, and persons discriminated on the basis of sex, sexual orientation, gender identity, age or disability. In the first case, qualified types of offences, higher criminal penalties, and a public prosecution procedure apply. In the second, there are basic types of crimes, lower criminal threats, and often a private prosecution mode. Moreover, the classification of an act motivated by hatred only under Articles 156, 157, 158, 190 or 217 PC does not reflect the criminal content of the act. In the light of the applicable legal regulation, persons belonging to the second group are therefore outside the scope of protection of the provisions of Articles 119, 256 and 257 PC. E. Zielińska believes that the need to extend the scope of criminalization by adding the features discussed to the catalogue is justified. ${ }^{44}$

The need to change the laws on hate speech towards people with disabilities has been repeatedly brought to the attention of the Polish Ombudsman. The function of the national human rights institution and independent monitoring body referred to in Article 33 (2) of the Convention on the Rights of Persons with Disabilities. ${ }^{45}$

${ }^{41}$ Article 55 of Directive 2012/29/EU of the European Parliament and of the Council of 25 October 2012 establishing minimum standards on the rights, support and protection of victims of crime, and replacing Council Framework Decision 2001/220/JHA (OJ EU L 315/57, 14.11.2012).

42 Articles 22 and 56 of Directive 2012/29/EU of the European Parliament and of the Council.

${ }^{43}$ M. Płatek, Mowa nienawiści - przesłanki depenalizacji, [in:] Mowa nienawiści a wolność wypowiedzi. Aspekty prawne i społeczne, eds. R. Wieruszewski, M. Wyrzykowski, A. Bodnar, A. Gliszczyńska-Grabias, Warszawa 2010, p. 911.

${ }^{44}$ E. Zielińska, Opinia w sprawie projektu zmian kodeksu karnego, [in:] Raport o homofobicznej mowie nienawiści w Polsce, Warszawa 2008, pp. 78-80.

45 Informacja Rzecznika Praw Obywatelskich o działaniach podjętych przez Rzeczpospolitą Polską w celu implementacji postanowień Konwencji o prawach osób niepełnosprawnych w latach 2015-2017, 31.01.2018, https://bip.brpo.gov.pl/sites/default/files/Informacja\%20RPO\%20 
In the Information to the UN Committee on the Implementation of the Convention on the Rights of Persons with Disabilities, the Polish Ombudsman made a negative assessment of the fact that the provisions of the Penal Code do not take into account a specific type of crime motivated by prejudice against persons with disabilities. In the Polish Ombudsman's view, hate speech against people with disabilities is not a crime at all and can only be prosecuted as an offence of insult prosecuted by private prosecution, which means that the burden of gathering evidence and bringing an accusation to court lies with the victim of the crime. In the opinion of the Polish Ombudsman, it is necessary to take a legislative initiative to extend the discriminatory grounds on the basis of disability. ${ }^{46}$

It is worth mentioning that on 16 February 2021 the Strategy for Persons with Disabilities for 2021-2030 was adopted. ${ }^{47}$ The Strategy clearly emphasizes that Article 8 of the Convention on the Rights of Persons with Disabilities obliges the State to take immediate, effective and appropriate measures to raise public awareness. The effect is to combat stereotypes, prejudices and harmful practices towards people with disabilities, including those related to gender and age, in all areas of life, and to promote awareness of the abilities and contributions of people with disabilities to society. This confirms not only the need for action to build public awareness of disability, including respect for the dignity and integrity of persons with disabilities, on an equal basis with others, and the right to live independently, but also for legal protection.

The Polish Ombudsman, in his comments to the proposals for the National Equal Treatment Action Programme for $2020-2030{ }^{48}$ stressed that building awareness is undoubtedly important for the elimination of hate crimes, but it cannot replace the necessary legal changes. Here, one has to agree with the statement that violence motivated by prejudice due to, among other things on the basis of disability,

dla\%20komitetu\%20ONZ\%20z\%20wdra\%C5\%BCania\%20\%20Konwencji\%20o\%20prawach\%20 os $\% \mathrm{C} 3 \%$ B3b $\% 20 z \% 20$ niepe $\% C 5 \% 82$ nosprawno\%C5\%9Bciam\%20(j\%C4\%99z.\%20polski)_0.pdf [access: 10.02 .2020 ].

46 See Pismo Rzecznika Praw Obywatelskich do Ministra Sprawiedliwości, 14.05.2020, XI.503.3.2020.MA, www.rpo.gov.pl/sites/default/files/Do\%20MS\%20ws\%20sytuacji\%20LGBTI\%2C\%2014.05.2020.pdf [access:10.02.2020]; Pismo Rzecznika Praw Obywatelskich do Prezesa Rady Ministrów z rekomendacjami, 19.02.2019, XI.518.50.2017.MS, www.rpo.gov.pl/sites/default/ files/Wyst $\%$ C4\%85pienie $\% 20$ do $\% 20$ Prezesa $\% 20$ Rady $\% 20$ Ministr $\% \mathrm{C} 3 \% \mathrm{~B} 3 \mathrm{w} \% 20 \mathrm{z} \% 20$ rekomendacjami\%20ws.\%20walki\%20z\%20mow\%C4\%85\%20nienawi\%C5\%9Bci.pdf [access:10.02.2020]; Raport „Przestępstwa motywowane uprzedzeniami. Analiza i zalecenia”, 22.12.2017, www.rpo.gov.pl/ $\mathrm{pl} /$ content/raport-przestepstwa-motywowane-uprzedzeniami-analiza-i-zalecenia [access:10.02.2020].

47 Resolution no. 27 of the Council of Ministers of 16 February 2021 (Polish Monitor 2021, item 218).

48 Uwagi RPO do Krajowego Programu Działań Równego Traktowania na lata 2020-2030 z dnia 1 grudnia 2020 r., 3.12.2020, www.rpo.gov.pl/pl/content/rpo-o-projekcie-programu-dzialan -na-rzecz-rownego-traktowania-2021-2030 [access: 11.02.2021]. 
as well as incitement to hatred on the basis of that characteristic, must be prohibited and prosecuted ex officio as specific acts punishable by a higher penalty. Such legal changes are necessary to make the fight against hate crime more effective so that people with disabilities who experience discrimination are protected.

Undoubtedly, the issue of criminalization of hate speech is one of the most controversial and most difficult to regulate areas of the issue of punishment for words. Due to the inability of hate speech to be covered by an unambiguous legal definition or a closed list of content that would be qualified as hateful, it is extremely difficult to determine through legal instruments the boundaries between permissible and prohibited speech ${ }^{49}$ The case-law of the European Court of Human Rights recognises, in principle, that it may be necessary for a democratic State to criminalise in national law content which promotes, incites or justifies hatred based on intolerance, provided that any measures taken by the State are necessary and proportionate to the aim pursue..$^{50}$ The Constitutional Tribunal in its decision clearly indicates that the Convention values and the foundations of a democratic society are tolerance and social peace, and "hate speech" is understood in a broad way, as speech advocating intolerance and discrimination against other people or social groups. This approach is broader than the dispositions of Polish criminal law, which are limited in this regard only to religious and nationality reasons. It is therefore right to include in the protection against hate speech people with disabilities, who find it more difficult to sufficiently care for their subjectivity, which is intrinsically linked to dignity.

It is difficult to agree with the objections that the criterion of "disability" is not sufficiently defined by statute. Introducing additional criteria such as the dependence of the protection of the person on the degree of disability can only increase the legislative chaos. Disability is a characteristic over which we generally have little control, it may be congenital or acquired, but it can never affect the protection of dignity. Therefore, maintaining proportionality between the appropriate level of protection of dignity and the limitations resulting from the feature of disability should be compensated for by including persons with disabilities in the catalogue of features subject to special protection against hate speech. Article $256 \mathrm{PC}$ should read: "Whoever publicly promotes a fascist or other totalitarian system of the state or incites hatred on the basis of national, ethnic, racial or religious differences or due to irreligiousness or disability, shall be subject to a fine, the penalty of restriction of liberty or imprisonment for up to 2 years". In this context, the introduction of criminal law protection of people with disabilities against hate speech is justified. It is, in fact, only compensation for the reduced ability to protect dignity due to a feature essentially independent of them.

49 A. Gliszczyńska-Grabias, op. cit., p. 45.

${ }^{50}$ Judgement of the ECtHR of 16 June 2009 in case Feret v. Belgium, application no. 15615/07. 


\section{CONCLUSIONS}

Human dignity is a fundamental inherent value that should be respected and protected equally in all people. Therefore, steps towards changes in legal protection should be guided by this principle in order to balance the interactions. Legal protection against hate speech requires an appropriate degree of protection and should serve to counteract discriminatory behaviour towards certain individuals or social groups.

It seems that legal changes in the field of penalizing hate speech relating to specific features, in this case disability, should be considered individually and preceded by a multifaceted legal analysis, taking into account international standards. Such an approach may reduce the risk of group rejection of all additional features due to worldview aspects. In this context, among the reasons for not introducing the criminalization of hate speech against people with disabilities, one can point to the fact of its combined introduction with other features that build controversy in the socio-political assessment. After analysing the opinions on the proposals amendments, it can be concluded that the legislator would be more willing to accept provisions limited only to the prohibition of discrimination on the grounds of disability. The separation of such a prohibition from other prohibitions of discrimination will of course not be effective without a whole system of legal and practical measures aimed at creating conditions for the realization of the rights of persons with disabilities, but it would certainly be the first step to clearly emphasize them.

The common element of all the justifications in terms of an amendment to extend the catalogue features subject to special protection from hate speech is the fact that proposals were characterized by insufficient justification for the issue of inalienable worth and dignity. The normative decision to intensify criminal repression of behaviour motivated by new discriminatory circumstances should be preceded by an appropriate analysis of the phenomenon. The project proponent must demonstrate that certain legal assets require enhanced protection, and in particular that existing legal instruments do not provide such protection or provide it at an insufficient level. Effective legal protection based on the individual feature of the victim requires a systemic approach taking into account the body of literature and international standards. In conclusion, it can be stated that the coverage of persons with disabilities against hate speech is not in doubt and should be based on ensuring adequate protection of dignity by the rule of law due to the balance of limitations resulting from a feature of disability that is essentially independent of them. 


\section{REFERENCES}

\section{Literature}

Andorno R., Human Dignity and Human Rights as a Common Ground for a Global Bioethics, "Journal of Medicine and Philosophy" 2009, vol. 34, DOI: https/doi.org/10.1093/jmp/jhp023.

Bieńkowska E., Wiktymologia, Warszawa 2018.

Borski M., Godność człowieka jako wartość uniwersalna, "Przegląd Prawa Publicznego" 2014, no. 3.

Chetty N., Alathur S., Hate speech review in the context of online social networks, "Aggression and Violent Behavior” 2018, vol. 40, DOI: https://doi.org/10.1016/j.avb.2018.05.003.

Cohen-Almagor R., Fighting Hate and Bigotry on the Internet, "Policy \& Internet" 2011, vol. 3(3), DOI: https://doi.org/10.2202/1944-2866.1059.

Demczuk A., Wolność wypowiedzi w orzecznictwie Europejskiego Trybunału Praw Człowieka a polskim prawie i praktyce sądowej, [in:] Europejska konwencja o ochronie praw człowieka - praktyka stosowania i funkcjonowanie w przestrzeni europejskiej, eds. M. Haczkowska, F. Tereszkiewicz, Opole 2016.

Deryng A., Zasada poszanowania godności osoby ludzkiej w praktyce konstytucyjnej Rzecznika Praw Obywatelskich, [in:] Wptyw standardów międzynarodowych na rozwój demokracji i ochronę praw czlowieka, ed. J. Jaskiernia, vol. 3, Warszawa 2013.

Gąciarz B., Model społeczny niepetnosprawności jako podstawa zmian w polityce społecznej, [in:] Polscy niepetnosprawni. Od kompleksowej diagnozy do nowego modelu polityki społecznej, eds. B. Gąciarz, S. Rudnicki, Kraków 2014.

Gibson B.E., Secker B., Rolfe D., Wagner F., Parke B., Mistry B., Disability and dignity-enabling home environments, "Social Science and Medicine" 2012, vol. 74(2),

DOI: https://doi.org/10.1016/j.socscimed.2011.10.006.

Gilabert P., Human Dignity and Human Rights, Oxford 2019.

Gliszczyńska-Grabias A., Międzynarodowe standardy wolności stowa a mowa nienawiści, [in:] Mowa nienawiści w Internecie. Jak z niq walczyć? Materiały z konferencji, eds. D. Bychawska-Siniarska, D. Głowacka, Warszawa 2013.

Granat M., Godność człowieka z art. 30 Konstytucji RP jako wartość i jako norma prawna, "Państwo i Prawo" 2014, no. 8.

Gruszecka D., Przestępstwa przeciwko porządkowi publicznemu, [in:] Kodeks karny. Część szczególna. Komentarz, ed. J. Giezek, Warszawa 2014.

Jacobson N., Dignity and health: A review, "Social Science \& Medicine" 2007, vol. 64(2), DOI: https://doi.org/10.1016/j.socscimed.2006.08.039.

Jaskuła L.K., Wolność działalności dziennikarskiej w perspektywie zjawiska mowy nienawiści (wybrane aspekty prawne), [in:] Status prawny dziennikarza, ed. W. Lis, Warszawa 2014.

Kuçuradi I., The concept of human dignity and its implications for human rights, "Bioethics Update" 2009, vol. 5, DOI: https://doi.org/10.1016/j.bioet.2019.02.001.

Lang R., The United Nations Convention on the right and dignities for persons with disability: A panacea for ending disability discrimination?, "Alter. European Journal of Disability Research" 2009, vol. 3(3), DOI: https://doi.org/10.1016/j.alter.2009.04.001.

Machowicz K., Jurydyczne uwarunkowania wolności wypowiedzi w Polsce jako kategoria praw człowieka w Polsce, Lublin 2012.

Metodyka pracy adwokata i radcy prawnego w sprawach o przestęsstwa z nienawiści, ed. P. Knut, Warszawa 2020.

Mikołajczyk B., Międzynarodowa ochrona praw osób straszych, Warszawa 2012.

Mikrut A., O odkrywaniu swojej godności przez osoby z niepełnosprawnościa intelektualna, "Annales UMCS. Sectio J" 2014, vol. 27(1). 
Mikrut A., O poszanowaniu godności osób niepetnosprawnych - idea a rzeczywistość, "Pielęgniarstwo i Zdrowie Publiczne" 2013, no. 3-4.

Mikrut A., O promowaniu godności człowieka w ramach Konwencji o prawach osób niepetnosprawnych, "Rocznik Komisji Nauk Pedagogicznych" 2016, vol. 69.

Mojski W., Prawnokarne ograniczenia wolności wypowiedzi w polskim porzadku prawnym: analiza wybranych przepisów, "Studia Iuridica Lublinensia" 2009, vol. 12.

Monedero J.A.G., Cuesta C.U., Angulo B.N., Social Image of Disability. Vulnerability of the Dignity of Women with Disability and Social Exclusion Contexts, "Procedia - Social and Behavioral Sciences" 2014, vol. 161, DOI: https://doi.org/10.1016/j.sbspro.2014.12.019.

Płatek M., Mowa nienawiści - przesłanki depenalizacji, [in:] Mowa nienawiści a wolność wypowiedzi. Aspekty prawne i społeczne, eds. R. Wieruszewski, M. Wyrzykowski, A. Bodnar, A. Gliszczyńska-Grabias, Warszawa 2010.

Polak P., Trzciński J., Konstytucyjna zasada godności człowieka w świetle orzecznictwa Trybunatu Konstytucyjnego, "Gdańskie Studia Prawnicze" 2018, no. 2.

Rogalska E., Urbańczyk M., Złożoność zjawiska mowy nienawiści w pozaprawnym aspekcie definicyjnym, "Studia nad Autorytaryzmem i Totalitaryzmem" 2017, vol. 39(2).

Szczupał B., Godność osoby z niepetnosprawnościa jako wyznacznik koncepcji praw człowieka, “Człowiek-Niepełnosprawność-Społeczeństwo" 2012, no. 3.

Śledzińska-Simon A., Decyzja ramowa w sprawie zwalczania pewnych form i przejawów rasizmu i ksenofobii jako trudny kompromis wobec mowy nienawiści w Unii Europejskiej, [in:] Mowa nienawiści a wolność słowa. Aspekty prawne i społeczne, eds. R. Wieruszewski, M. Wyrzykowski, A. Bodnar, A. Gliszczyńska-Grabias, Warszawa 2010.

Zdravkova K., Reconsidering Human Dignity in the New Era, "New Ideas in Psychology" 2019, vol. 54, DOI: https://doi.org/10.1016/j.newideapsych.2018.12.004.

Zielińska E., Opinia w sprawie projektu zmian kodeksu karnego, [in:] Raport o homofobicznej mowie nienawiści w Polsce, Warszawa 2008.

Zieliński S., Rozumienie godności człowieka i jej znaczenie w procesie stanowienia i stosowania prawa. Propozycja testu zgodności regulacji prawnych z zasada godności człowieka, "Przegląd Sejmowy" 2019, no. 4, DOI: https://doi.org/10.31268/PS.2019.54.

\section{Online sources}

Informacja Rzecznika Praw Obywatelskich o działaniach podjętych przez Rzeczpospolitą Polską w celu implementacji postanowień Konwencji o prawach osób niepełnosprawnych w latach 20152017, 31.01.2018, https://bip.brpo.gov.pl/sites/default/files/Informacja\%20RPO\%20dla\%20 komitetu $\% 20 \mathrm{ONZ} \% 20 \mathrm{z} \% 20 \mathrm{wdra} \% \mathrm{C} 5 \%$ BCania $\% 20 \% 20$ Konwencji\%20o\%20prawach $\% 20$ os\%C3\%B3b\%20z\%20niepe $\%$ C5\%82nosprawno\%C5\%9Bciam\%20(j\%C4\%99z.\%20polski)_0. pdf [access: 10.02.2020].

Pismo Rzecznika Praw Obywatelskich do Ministra Sprawiedliwości, 14.05.2020, XI.503.3.2020. MA, www.rpo.gov.pl/sites/default/files/Do\%20MS\%20ws\%20sytuacji\%20LGBTI\%2C\%20 14.05.2020.pdf [access:10.02.2020].

Pismo Rzecznika Praw Obywatelskich do Prezesa Rady Ministrów z rekomendacjami, 19.02.2019, XI.518.50.2017.MS, www.rpo.gov.pl/sites/default/files/Wyst $\%$ C4\%85pienie $\% 20 \mathrm{do} \% 20$ Prezesa $\% 20$ Rady $\% 20$ Ministr $\%$ C3\%B3w\%20z\%20rekomendacjami\%20ws. $\% 20$ walki $\% 20 z \% 20$ mow\%C4\%85\%20nienawi\%C5\%9Bci.pdf [access:10.02.2020].

Raport „Przestępstwa motywowane uprzedzeniami. Analiza i zalecenia”, 22.12.2017, www.rpo. gov.pl/pl/content/raport-przestepstwa-motywowane-uprzedzeniami-analiza-i-zalecenia [access:10.02.2020]. 
Pobrane z czasopisma Studia Iuridica Lublinensia http://studiaiuridica.umes.pl Data: 26/04/2023 08:01:36

Protection of Human Dignity as a Basis for Penalization of Hate Speech against People... 279

Uwagi RPO do Krajowego Programu Działań Równego Traktowania na lata 2020-2030 z dnia 1 grudnia 2020 r., 3.12.2020, www.rpo.gov.pl/pl/content/rpo-o-projekcie-programu-dzialan-na-rzecz-rownego-traktowania-2021-2030 [access: 11.02.2021].

\section{Legal acts}

Act of 6 June 1997 - Penal Code (consolidated text, Journal of Laws 2020, item 1444, as amended). Constitution of the Republic of Poland of 2 April 1997 (Journal of Laws 1997, no. 78, item 483, as amended).

Convention on the Rights of Persons with Disabilities adopted by the UN General Assembly on 13 December 2006 (Journal of Laws 2012, item 1169, as amended).

Directive 2012/29/EU of the European Parliament and of the Council of 25 October 2012 establishing minimum standards on the rights, support and protection of victims of crime, and replacing Council Framework Decision 2001/220/JHA (OJ EU L 315/57, 14.11.2012).

Recommendation no. R (97) 20 of the Committee of Ministers to Member States on "hate speech", adopted by the Committee of Ministers on 30 October 1997.

Resolution no. 27 of the Council of Ministers of 16 February 2021 (Polish Monitor 2021, item 218).

\section{Case law}

Decision of the Supreme Court of 5 February 2007, IV KK 406/06, OSNwSK 2007, no. 1, item 367. Judgement of the Constitutional Tribunal of 25 February 2014, SK 65/12, OTK 2014, no. 2, item 14. Judgement of the ECtHR of 16 June 2009 in case Feret v. Belgium, application no. 15615/07. Judgement of the Supreme Court of 8 February 2019, IV KK 38/18, LEX no. 2621830.

\section{ABSTRAKT}

Celem pracy jest analiza prawna przepisów kryminalizujących mowę nienawiści w polskim prawie karnym w zakresie ochrony przyrodzonej godności człowieka w odniesieniu do osób z niepełnosprawnościami. Oceniono, czy brak szczególnej ochrony prawnokarnej w obszarze mowy nienawiści zapewnia należyty szacunek i ochronę godności osób z niepełnosprawnościami w Polsce w takim samym zakresie i stopniu jak innych osób. Omówiono doktrynę ochrony prawnokarnej przed mową nienawiści. Przeanalizowano przyczyny niewprowadzenia penalizacji mowy nienawiści wobec osób z niepełnosprawnościami i wykazano, że zmiany prawne w tym zakresie powinny być poprzedzone wieloaspektową analizą prawną z uwzględnieniem standardów międzynarodowych, a projekty nowelizacji cechowały się niewystarczającym uzasadnieniem kwestii niezbywalnej wartości godności. Przeprowadzono dyskusję w zakresie podstaw penalizacji mowy nienawiści wobec osób z niepełnosprawnościami. Wykazano, że objęcie osób z niepełnosprawnościami ochroną przed mową nienawiści nie budzi wątpliwości i powinno opierać się na zapewnieniu odpowiedniej ochrony godności przez państwo prawa ze względu na zrównoważenie ograniczeń wynikających z cechy niepełnosprawności, która jest zasadniczo od nich niezależna.

Słowa kluczowe: ochrona prawnokarna; osoby z niepełnosprawnościami; godność człowieka; mowa nienawiści 